\title{
Raised TSH is associated with endothelial dysfunction in Metabolic Syndrome: A case control study
}

\author{
ASHOK KUMAR AHIRWAR, ARCHANA SINGH, ANJU JAIN, SURAJEET KUMAR PATRA, \\ BINITA GOSWAMI, M.K. BHATNAGAR, JAYASHREE BHATTACHARJEE
}

Department of Biochemistry and Medicine, Lady Hardinge Medical College and S. S. K Hospital, New Delhi, India

\begin{abstract}
Introduction. Endothelial dysfunction has been considered as one of the important factors in pathogenesis of Metabolic Syndrome (Met S). Subclinical hypothyroidism (SCH) has also been reported to be associated with Met S. The aim of our study is to evaluate the association of raised TSH with mediators of endothelial dysfunction in Met $\mathrm{S}$ with Subclinical hypothyroidism as compared to healthy controls.

Methods. Study population consisted of 100 subjects, out of which 50 were cases of Met S and 50 were healthy controls. Met $\mathrm{S}$ group were further divided into two, based on the presence \& absence of $\mathrm{SCH}$. Serum insulin, $\mathrm{T}_{3}, \mathrm{~T}_{4}$, TSH were measured by chemiluminescence based immunoassay (CLIA). Serum nitric oxide (NO) levels were measured by Modified Griess's method and serum endothelin-1 (ET-1) levels were measured by ELISA.

Results. Out of 50 cases of Met S, SCH was diagnosed in 22. The mean serum TSH levels were significantly higher in Met $\mathrm{S}$ cases as compared to healthy controls $(5.7 \pm 1.2 \mu \mathrm{IU} / \mathrm{mL} v s .2 .3 \pm$ $1.6 \mu \mathrm{IU} / \mathrm{mL}, P<0.0001)$. Mean serum NO levels were significantly lower in Met $\mathrm{S}$ cases as compared to healthy control $(15.4 \pm 10 \mu \mathrm{M}$ vs. $21 \pm 10 \mu \mathrm{M}, p=0.009)$. Mean serum ET-1 levels were significantly higher in Met $\mathrm{S}$ cases as compared to healthy controls $(2.68 \pm 1.7 \mathrm{fmol} / \mathrm{mL} v s .2 .1 \pm$ $0.84 \mathrm{fmol} / \mathrm{mL}, p=0.011)$. On Pearson's correlation analysis, TSH showed positive correlation with ET-1 $(r=0.341, p=0.001)$ and negative correlation with NO $(r=-0.331, p=0.001)$. Binary logistic regression analysis showed that TSH, NO and ET-1 has significant odd's ratio for predicting Met S.

Conclusion. Met $\mathrm{S}$ cases were screened for thyroid abnormalities and found to have $44 \%$ of $\mathrm{SCH}$ along with co-existing endothelial dysfunction. Raised TSH in $\mathrm{SCH}$ could cause endothelial dysfunction which may lead to Met S and associated co-morbidities. Present study gives new insight in linking endothelial dysfunction and raised TSH in Met S. Therefore, Met S cases should be screened for SCH and treated appropriately to attenuate endothelial dysfunction and associated comorbidities in Met S.
\end{abstract}

Key words: Metabolic Syndrome X, Hypothyroidism, Nitric Oxide, Endothelin-1.

\section{INTRODUCTION}

Metabolic Syndrome (Met S) consists of various metabolic abnormalities such as central obesity, impaired fasting glucose, dyslipidemia, and hypertension. Met $\mathrm{S}$ increases the future risk of diabetes by 3 times and cardiovascular disease by 5 times which is considered as major health issue [1].

It has been seen that approximately $20-25 \%$ of the world's adult population is suffering from Met S [2]. Around 34\% of US population has Met S [3]. In India, the overall prevalence of Met $\mathrm{S}$ is around $33.5 \%$ and it is lower in males $(24.9 \%)$ as compared to females (42.3\%) according to Prasad DS et al. [4].

It has been reported that endothelial dysfunction plays an important role in the pathogenesis of Met $\mathrm{S}$ [5]. Endothelial dysfunction is defined as diminished bioavailability of nitric oxide (NO) and/or an increase in vasoconstrictive factors such as endothelin (ET-1).
It has been seen that when Met $\mathrm{S}$ is properly treated then endothelial dysfunction is reversed and it is an independent risk factor for adverse cardiovascular outcome [6]. It has been seen that thyroid dysfunction, in the form of sub clinical hypothyroidism $(\mathrm{SCH})$, increases the risk of coronary vascular disease (CVD), possibly through endothelial dysfunction and dyslipidemia [7].

Therefore the aim of our study was to evaluate the role of $\mathrm{SCH}$ in causing endothelial dysfunction in Met S. We hypothesized that raised TSH in SCH is associated with endothelial dysfunction which may lead to Met $\mathrm{S}$.

\section{MATERIAL AND METHODS}

The present study is a descriptive observational case control study conducted in the Department of Biochemistry and Medicine, Lady Hardinge Medical 
College, New Delhi from 2012-2015. The study was approved by the ethical committee of LHMC, New Delhi.

50 cases of Met $\mathrm{S}$ diagnosed as per IDF guidelines and 50 age and sex matched healthy controls were enrolled. IDF (International Diabetic Federation) guidelines include central obesity and any of the following 1) Raised triglycerides: $>150 \mathrm{mg} / \mathrm{dL}$ or specific treatment for this lipid abnormality, 2) Reduced HDL cholesterol: $<40 \mathrm{mg} / \mathrm{dL}$ in males, $<50 \mathrm{mg} / \mathrm{dL}$ in females, or specific treatment for this lipid abnormality, 3) Raised blood pressure (BP): systolic BP $>130$ or diastolic $\mathrm{BP}>85 \mathrm{~mm} \mathrm{Hg}$, or treatment of previously diagnosed hypertension, 4) Raised fasting plasma glucose (FPG): $>100 \mathrm{mg} / \mathrm{dL}(5.6 \mathrm{mmol} / \mathrm{L})$, or previously diagnosed type 2 diabetes.

Cases of Met $\mathrm{S}$ were further divided into two groups based on thyroid function test. 1st group consisted of Met S cases with $\mathrm{SCH}$ and the second group consisted of Met $\mathrm{S}$ cases without $\mathrm{SCH}$.

Inclusion criteria. Diagnosed case of Met $\mathrm{S}$ as per IDF was included in the study.

Exclusion criteria. Subjects who were known case of thyroid dysfunction or on medication with thyroxine and antithyroid drugs or any drug which can affect thyroid function, patients with acute and chronic disorders such as autoimmune diseases, cardiac diseases, connective tissue diseases, liver and kidney diseases, and malignancy were excluded from the study.

\section{SAMPLING}

$5 \mathrm{~mL}$ venous blood was collected in plain vial from the study subject under sterile condition after an overnight fasting of 8-12 hrs. The whole blood was allowed to clot for half an hour and then centrifuged at $5000 \mathrm{rpm}$ for 5 minutes. After separation of serum, it was divided into two aliquots, one aliquot was immediately sent to biochemical clinical lab for routine investigations and hormone profiling. All routine biochemical investigations were done on fully automated analyzer from Beckman Coulter Random access CX-4 and CX-9 series (California, USA) by reagents provided by Sentinel diagnostics (Milan, Italy), Centronic GmbH Reagents, In-vitrodiagnostics (Germany), Randox Laboratories (United Kingdom), Beckmann Coulter- Clinical Diagnostic (California, USA), and Merck \& Co (Germany).

Thyroid profile in the form of serum $\mathrm{T}_{3}, \mathrm{~T}_{4}$ and TSH was done on Access 2 Immunoassay System, Beckmann Coulter- Clinical Diagnostic (California, USA) by closed system reagents pack provided by Beckmann Coulter - Clinical Diagnostic. Normal reference value of $\mathrm{T}_{3}=2.5-3.9 \mathrm{pg} / \mathrm{mL}, \mathrm{T}_{4}=$ $0.6-1.12 \mathrm{ng} / \mathrm{dL}$ and $\mathrm{TSH}=0.34-5.6 \mu \mathrm{IU} / \mathrm{mL}$ was considered.

Second aliquot of serum samples were stored at $-20^{\circ} \mathrm{C}$ till subsequent analysis for special investigation such as Nitric oxide and Endothelin.

\section{SERUM NO MEASUREMENT BY MODIFIED GRIESS REACTION}

Since NO is a very unstable molecule, it is difficult to measure as it is decomposed to form nitrite $\left(\mathrm{NO}_{2}{ }^{-}\right)$and nitrate $\left(\mathrm{NO}_{3}{ }^{-}\right)$in the presence of oxygen. Nitrite, a stable end product, was estimated as an index of NO using Modified Greiss reaction which involves the formation of a chromophore during the reaction of nitrite $\left(\mathrm{NO}_{2}^{-}\right)$with sulfanilamide and heterocyclic amine of $\mathrm{N}$-(1-naphthyl) ethylenediamine (Griess reagent) at low $\mathrm{pH}$ to form a magenta colored compound, which was measured spectrophotometrically [8].

\section{SERUM ENDOTHELIN (ET-1) MEASUREMENT BY ELISA}

Serum ET-1 was determined using the commercially available, human ET-1 Enzyme Immuno Assay kit by Biomedica Gruppe ELISA kit (Vienna, Divischgasse, Austria).

\section{STATISTICAL ANALYSIS}

Statistical analysis was done by using SPSS version 20.0 software (SPSS Inc., Chicago, IL, USA) and GraphPad Prism version 5 (GraphPad Software, Inc. CA, USA). Data of the study population were expressed as mean $\pm \mathrm{SD}$. Categorical data was analyzed by Chi-square test. Student's "t" test was used to measure mean of study variables between the Met $\mathrm{S}$ group and the control group. ANOVA analysis was used to analyse the mean in more than two groups. Pearson correlation was used to determine if any significant relationship is present among the study variables. Binary logistic regression analysis was used to assess the predictability of study variables for Met $\mathrm{S}$. The $p$ value of $<0.05$ was considered statistically significant.

\section{RESULTS}

Study population consisted of 100 subjects and it was divided into 50 cases of Met $\mathrm{S}$ and 
50 healthy controls. 22 Met $\mathrm{S}$ cases were found to have subclinical hypothyroidism $(\mathrm{SCH})$ and 3 cases of Met S had overt hypothyroidism. In healthy control group only 4 healthy individuals had $\mathrm{SCH}$ and the difference between two groups was found to be statistically significant as shown in Table 1 .

Table 1

The distribution of thyroid dysfunction in Met $\mathrm{S}$ cases and Healthy Control

\begin{tabular}{|l|c|c|l|}
\hline & $\begin{array}{c}\text { Met S } \\
\text { cases }\end{array}$ & Control & p value \\
\hline Sub clinical Hypothyroidism & 22 & 4 & $<0.05^{*}$ \\
\hline Hypothyroidism & 3 & 0 & \\
\hline
\end{tabular}

${ }^{*} \mathrm{p}$ value $\leq 0.05$ is considered statistically significant.

DEMOGRAPHIC, ANTHROPOMETRIC AND BIOCHEMICAL PROFILE OF STUDY POPULATION

Our study was age and sex matched. As shown in Table 1, our Met S group had obesity and associated features such as deranged Glucose and Lipid Profile compared to healthy control.

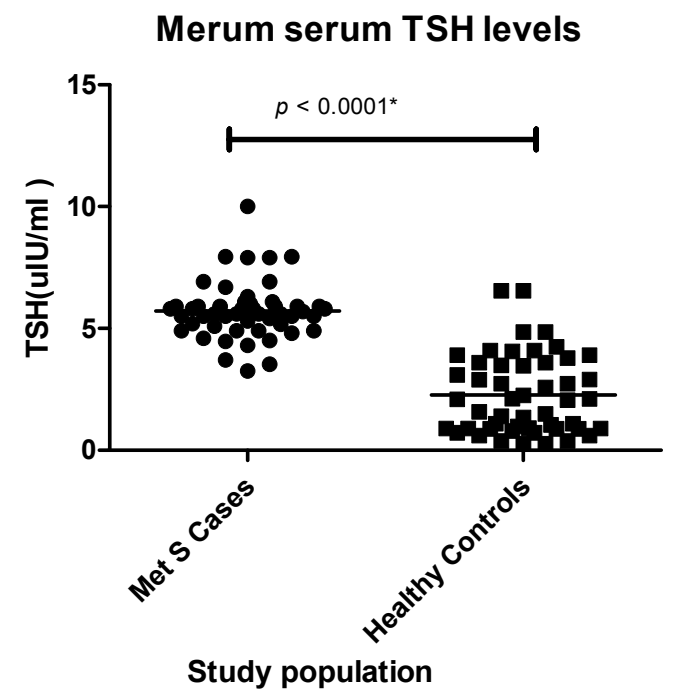

\section{THYROID FUNCTION STATUS IN STUDY POPULATION}

As shown in Table 2 and Figure 1, mean $\mathrm{T}_{3}$ and $\mathrm{T}_{4}$ levels were not statistically different in two groups, while mean TSH levels were significantly higher in Met $\mathrm{S}$ cases than in controls $(5.7 \pm$ $1.2 \mu \mathrm{IU} / \mathrm{mL} v s .2 .3 \pm 1.6 \mu \mathrm{IU} / \mathrm{mL}, P<.0001)$.

Table 2

Demographic, anthropometric and biochemical profile of study population

\begin{tabular}{|l|c|c|c|}
\hline \multicolumn{1}{|c|}{ Parameters } & $\begin{array}{c}\text { Cases } \\
(\mathbf{n}=\mathbf{5 0}) \\
(\mathbf{m e a n} \pm \mathbf{\text { SD}})\end{array}$ & $\begin{array}{c}\text { Control } \\
(\mathbf{n}=\mathbf{5 0}) \\
(\mathbf{m e a n} \pm \mathbf{S D})\end{array}$ & $\boldsymbol{p}$ value \\
\hline BMI $\left(\mathrm{Kg} / \mathrm{m}^{2}\right)$ & $28 \pm 5.4$ & $25 \pm 4.4$ & $0.002^{*}$ \\
\hline Waist Hip Ratio & $0.96 \pm 0.09$ & $0.93 \pm 0.04$ & $0.025^{*}$ \\
\hline Systolic BP & $132 \pm 12$ & $122 \pm 9$ & $0.000^{*}$ \\
\hline Diastolic BP & $86 \pm 8$ & $81 \pm 5$ & $0.001^{*}$ \\
\hline Total Cholesterol $(\mathrm{mg} / \mathrm{dL})$ & $240.7 \pm 91.5$ & $246.5 \pm 87$ & 0.781 \\
\hline Triglyceride $(\mathrm{mg} / \mathrm{dL})$ & $182.7 \pm 112$ & $141.5 \pm 64.8$ & $0.026^{*}$ \\
\hline HDL $(\mathrm{mg} / \mathrm{dL})$ & $38.8 \pm 10$ & $49.2 \pm 11$ & $0.00^{*}$ \\
\hline LDL $(\mathrm{mg} / \mathrm{dL})$ & $36.5 \pm 22.4$ & $28.3 \pm 13$ & $0.026^{*}$ \\
\hline VLDL & $38.6 \pm 10$ & $49.1 \pm 11.2$ & $0.023^{*}$ \\
\hline FPG $(\mathrm{mg} / \mathrm{dL})$ & $181.3 \pm 70.9$ & $96.3 \pm 7.5$ & $0.000^{*}$ \\
\hline PPBG $(\mathrm{mg} / \mathrm{dL})$ & $232.4 \pm 94$ & $140.74 \pm 142$ & $0.000^{*}$ \\
\hline
\end{tabular}

$* p$ value $\leq 0.05$ is considered statistically significant.

\section{Serum TSH levels}

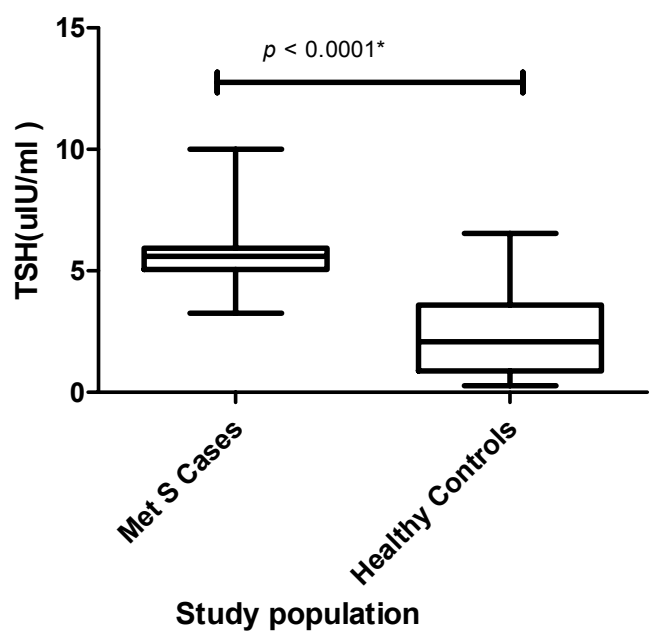

Figure 1. Serum TSH in study population.

\section{MEDIATORS OF ENDOTHELIAL DYSFUNCTION IN STUDY POPULATION}

As shown in Table 4, Figures 2 and 3, the mean serum NO levels were significantly lower in cases of Met $\mathrm{S}$ as compared to healthy controls $(15.4 \pm 10 \mu \mathrm{M} v s 21 \pm 10 \mu \mathrm{M}, p=0.009)$ and mean serum endothelin-1 levels were significantly higher in Met $\mathrm{S}$ cases as compared to healthy controls $(2.68 \pm 1.7 \mathrm{fmol} / \mathrm{L}$ vs $2.1 \pm 0.8 \mathrm{fmol} / \mathrm{L}, p=0.011)$.
This shows that endothelial dysfunction plays an important role in the pathogenesis of Met S.

Table 3

Thyroid profile of study population

\begin{tabular}{|l|c|c|c|}
\hline \multicolumn{1}{|c|}{ Parameters } & $\begin{array}{c}\text { Cases } \\
(\mathbf{n}=\mathbf{5 0}) \\
(\mathbf{m e a n} \pm \text { SD) }\end{array}$ & $\begin{array}{c}\text { Controls } \\
(\mathbf{n}=\mathbf{5 0}) \\
(\mathbf{m e a n} \pm \text { SD) }\end{array}$ & $\boldsymbol{p}$ value \\
\hline $\mathrm{T}_{3}(\mathrm{pg} / \mathrm{mL})$ & $3.6 \pm 0.9$ & $3.8 \pm 1.3$ & 0.375 \\
\hline $\mathrm{T}_{4}(\mathrm{ng} / \mathrm{dL})$ & $0.92 \pm 0.21$ & $0.92 \pm 0.37$ & 0.984 \\
\hline $\mathrm{TSH}(\mu \mathrm{UI} / \mathrm{mL})$ & $5.7 \pm 1.2$ & $2.3 \pm 1.6$ & $0.000^{*}$ \\
\hline
\end{tabular}

${ }^{*} p$ value $\leq 0.05$ is considered statistically significant. 
Table 4

Mean level of markers of endothelial dysfunction in study population

\begin{tabular}{|l|c|c|c|}
\hline \multicolumn{1}{|c|}{ Parameters } & $\begin{array}{c}\text { Cases } \\
(\mathbf{n}=\mathbf{5 0}) \\
(\mathbf{m e a n} \pm \mathbf{S D})\end{array}$ & $\begin{array}{c}\text { Controls } \\
(\mathbf{n = 5 0 )} \\
(\mathbf{m e a n} \pm \mathbf{S D})\end{array}$ & $\boldsymbol{p}$ value \\
\hline Nitric Oxide $(\mu \mathrm{M})$ & $15.4 \pm 10$ & $21 \pm 10$ & $0.009^{*}$ \\
\hline Endothelin-1 $(\mathrm{fmol} / \mathrm{mL})$ & $2.68 \pm 1.7$ & $2.1 \pm 0.84$ & $0.011^{*}$ \\
\hline
\end{tabular}

${ }^{*} \mathrm{p}$ value $\leq 0.05$ is considered statistically significant.

Moreover, on ANOVA analysis, the mean serum NO levels were found to be lower in Met S cases with thyroid dysfunction (Sub Clinical Hypothyroidism and Overt Hypothyroidism) as compared to Met S cases without thyroid dysfunction. Even mean serum ET-1 levels were higher in Met S cases with thyroid dysfunction (Sub Clinical Hypothyroidism and Overt Hypothyroidism) as compared to Met $\mathrm{S}$ cases without thyroid dysfunction as shown in Table 5, Figures 4 and 5, but the difference was not found to be statistically significant, this may be attributed to small sample size.

\section{Mean serum NO levels}

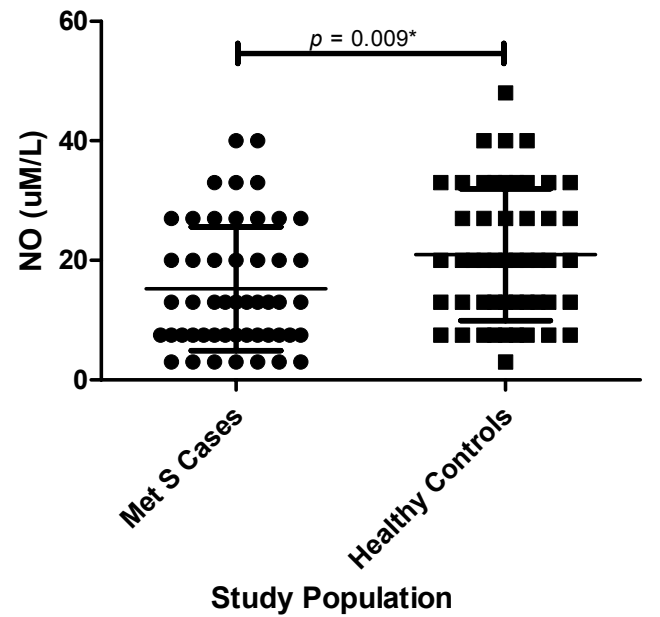

\section{Serum NO levels}

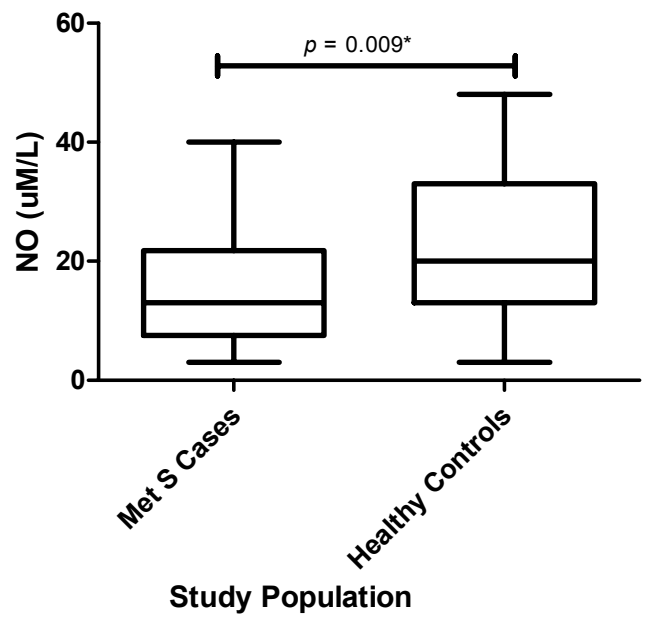

Figure 2. Serum NO in study population.
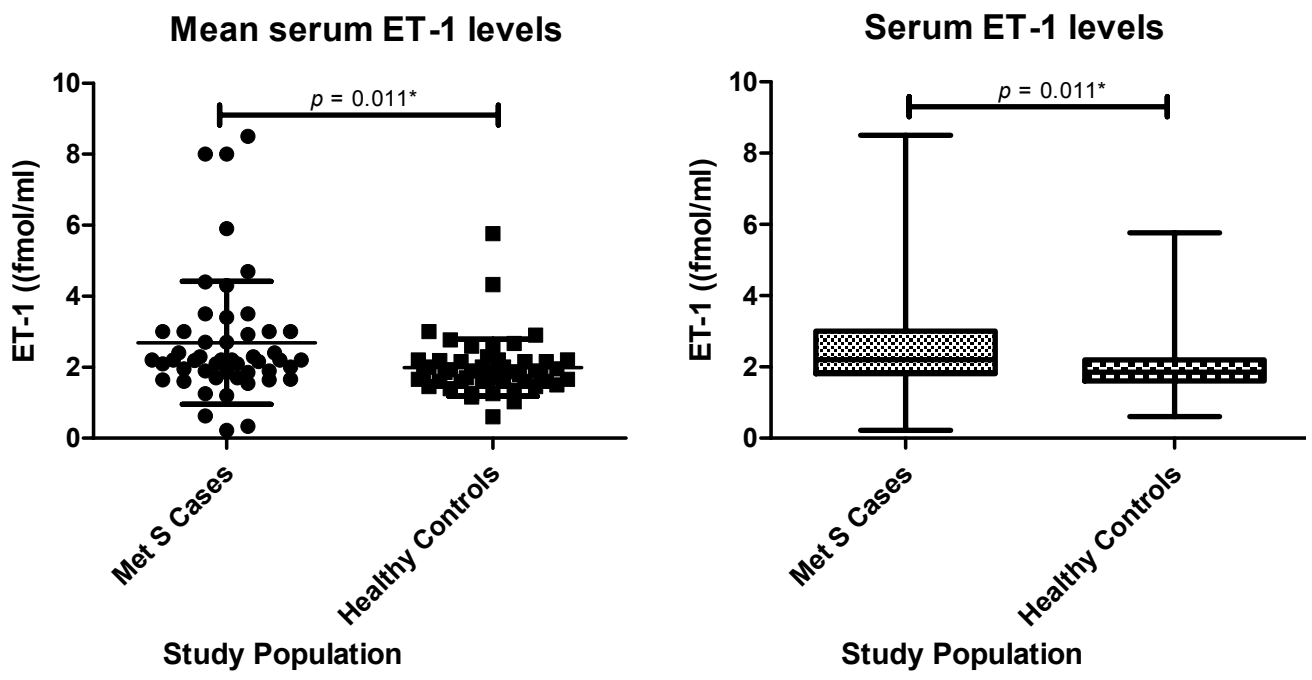

Figure 3. Serum ET-1 in study population.

Table 5

Mean serum NO and Endothelin-1 levels in thyroid abnormalities of Metabolic Syndrome cases

\begin{tabular}{|l|c|c|}
\hline \multicolumn{1}{|c|}{$\begin{array}{c}\text { Thyroid Abnormalities } \\
\text { in Met S cases }\end{array}$} & $\begin{array}{c}\text { Serum NO levels } \\
\text { (Mean } \pm \text { SD) }\end{array}$ & $\begin{array}{c}\text { Serum Endothelin-1 levels } \\
\text { (Mean } \pm \text { SD) }\end{array}$ \\
\hline Euthyroid & $16.5 \pm 11 \mu \mathrm{M}$ & $2.6 \pm 1 \mathrm{fmol} / \mathrm{mL}$ \\
\hline Sub Clinical Hypothyroidism $(\mathrm{SCH})$ & $14.4 \pm 9 \mu \mathrm{M}$ & $3.1 \pm 1.8 \mathrm{fmol} / \mathrm{mL}$ \\
\hline Overt Hypothyroidism & $13.7 \pm 6 \mu \mathrm{M}$ & $4.3 \pm 3.3 \mathrm{fmol} / \mathrm{mL}$ \\
\hline
\end{tabular}



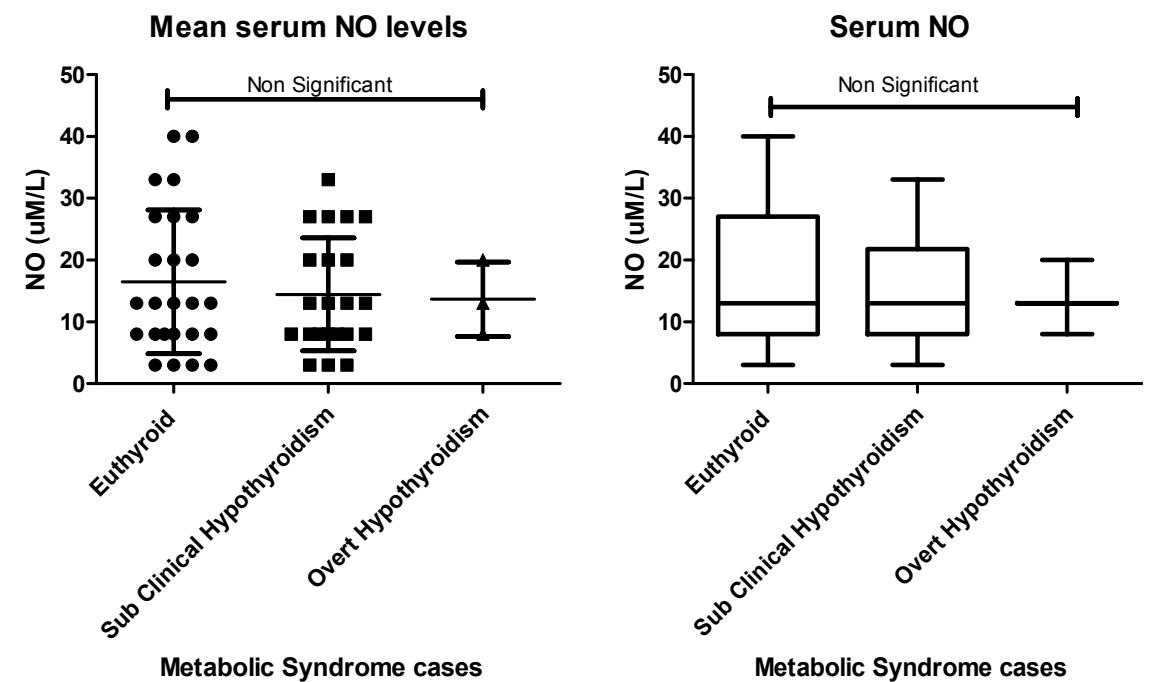

Figure 4. Serum NO levels in Euthyroid, Sub clinical hypothyroidism and Overt hypothyroidism individuals with Metabolic Syndrome.
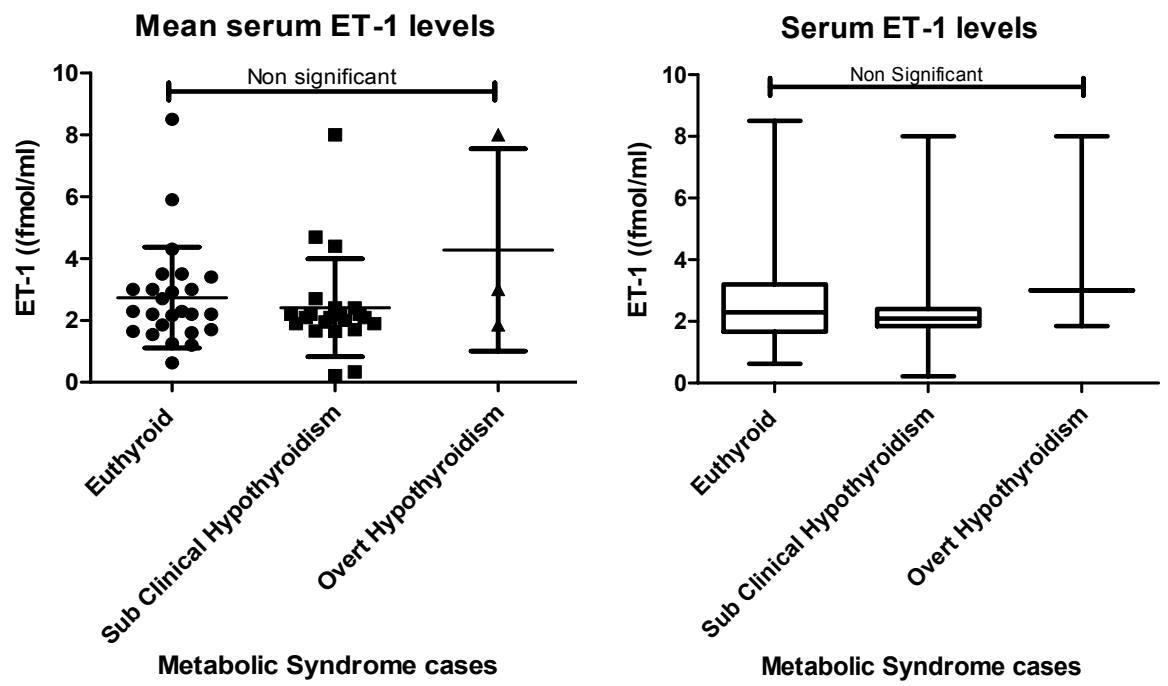

Figure 5. Serum ET-1 levels in Euthyroid, Sub clinical hypothyroidism and Overt hypothyroidism individuals with Metabolic Syndrome.

\section{CORRELATION ANALYSIS OF TSH, NO AND ET-1}

On Pearson's correlation, serum TSH showed positive correlation with BMI, systolic and diastolic BP, Fasting Blood Glucose, Post Prandial Blood Glucose, serum Triglycerides and ET-1 and negative correlation with HDL cholesterol and NO although BMI, systolic and diastolic BP, Fasting Blood Glucose, HDL cholesterol and NO showed a statistically significant correlation as shown in Table 6, Figures 6 and 7.

Table 6

Correlation of TSH with study variables

\begin{tabular}{|l|c|c|c|c|c|c|}
\hline \multicolumn{1}{|c|}{ Parameters } & \multicolumn{2}{c|}{ TSH } & \multicolumn{2}{c|}{ NO } & \multicolumn{2}{c|}{ Endothelin-1 } \\
\hline & r value & $\boldsymbol{p}$ value & r value & $\boldsymbol{p}$ value & r value & $\boldsymbol{p}$ value \\
\hline BMI & 0.240 & $0.016^{*}$ & -0.180 & 0.073 & -0.013 & 0.897 \\
\hline Systolic BP & 0.252 & $0.011^{*}$ & -0.162 & 0.107 & 0.042 & 0.677 \\
\hline Diastolic BP & 0.231 & $0.020^{*}$ & -0.020 & 0.841 & -0.006 & 0.951 \\
\hline FBG & 0.433 & $0.000^{*}$ & -0.182 & 0.071 & 0.231 & $0.020^{*}$ \\
\hline PPBS & 0.190 & 0.058 & -0.031 & 0.759 & 0.169 & 0.093 \\
\hline Triglyceride (TG) & 0.219 & 0.280 & -0.130 & 0.901 & 0.189 & 0.060 \\
\hline HDL Cholesterol & -0.39 & $0.000^{*}$ & 0.092 & 0.361 & -0.121 & 0.230 \\
\hline Endothelin-1 & 0.341 & $0.001^{*}$ & -0.06 & 0.955 & 1 & - \\
\hline TSH & 1 & - & -0.331 & $0.001^{*}$ & 0.34 & $0.001^{*}$ \\
\hline NO & -0.331 & $0.001^{*}$ & 1 & - & -0.06 & 0.955 \\
\hline
\end{tabular}

$* p$ value $\leq 0.05$ is considered statistically significant. 
Correlation between TSH and NO

Correlation between TSH and ET-1
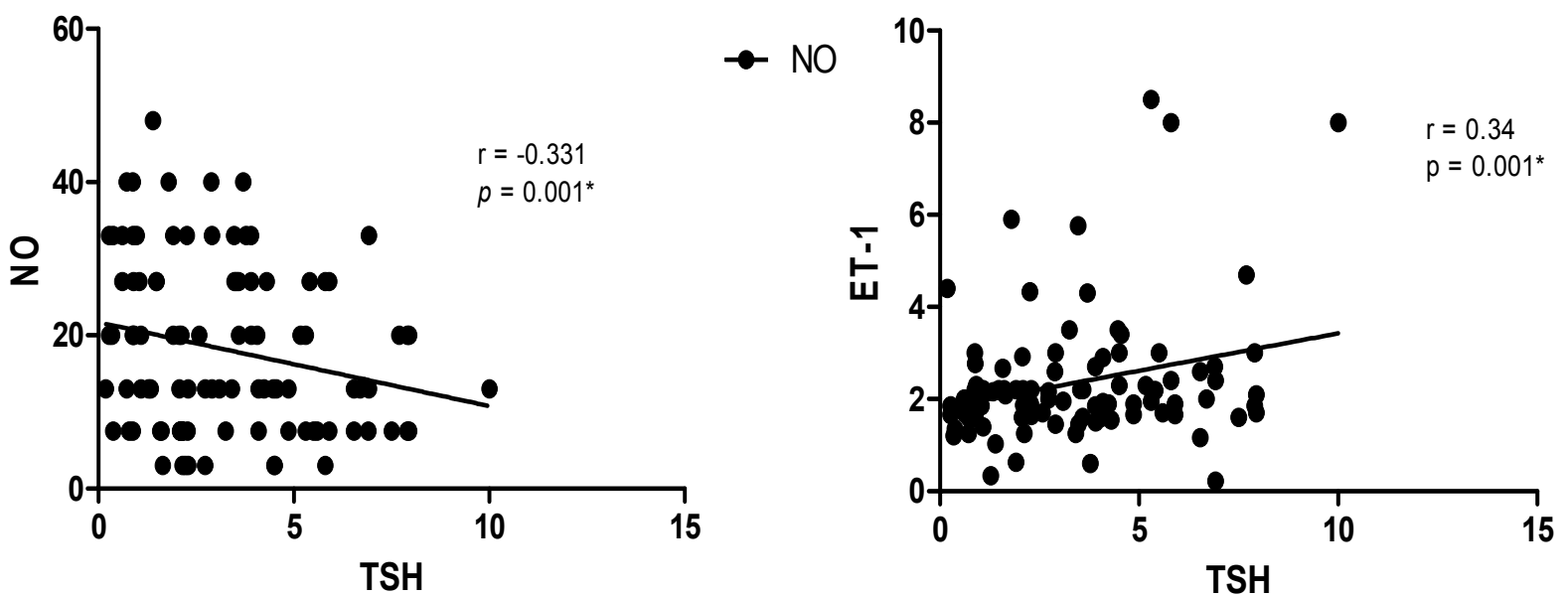

Figure 6. Pearson's correlation analysis of TSH with NO and ET-1.

Subclinical Hypothyroidism in Metabolic Syndrome

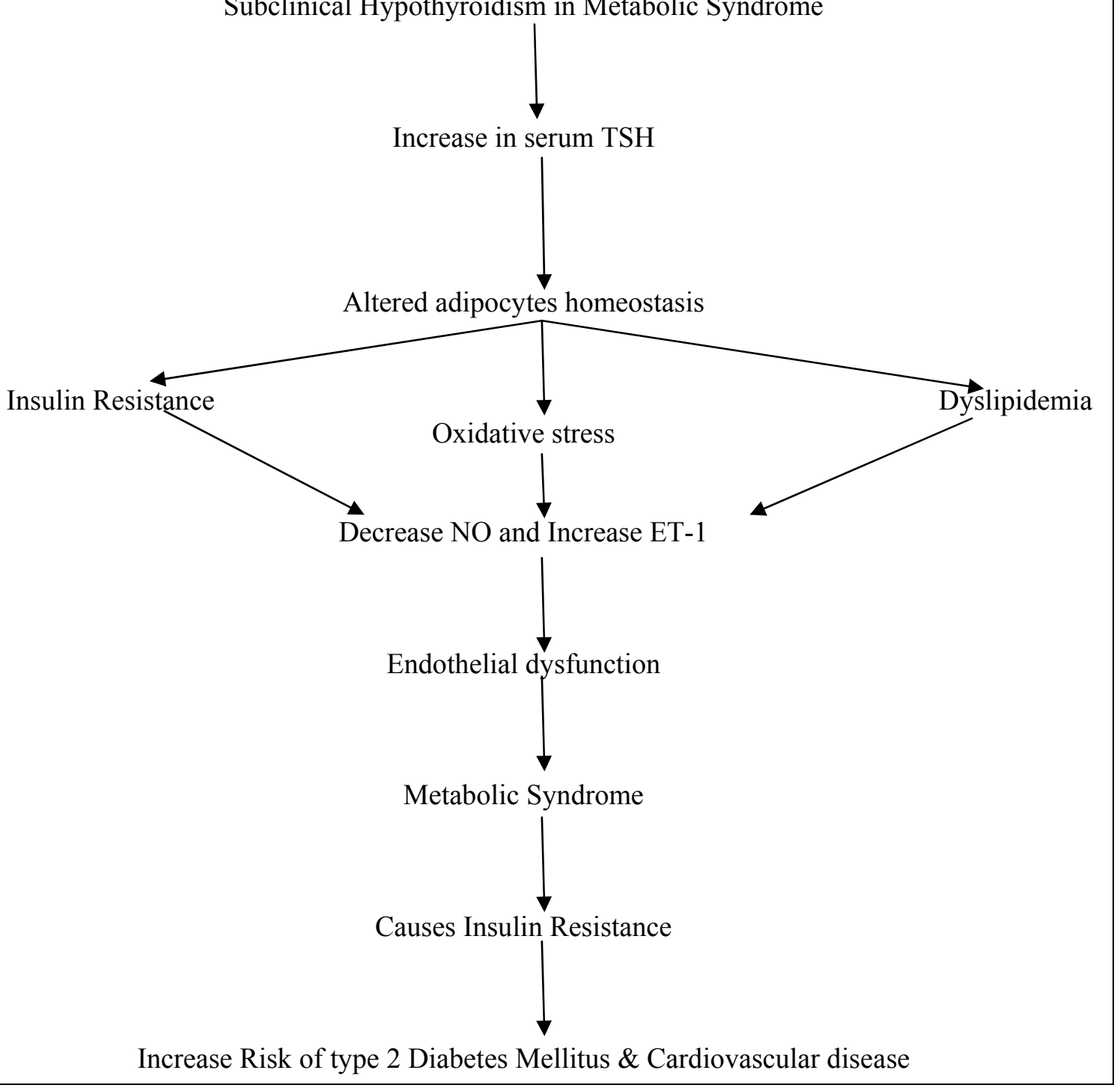

Figure 7. Probable link between the raised TSH in SCH and endothelial dysfunction in Metabolic Syndrome according to our study. 


\section{BINARY LOGISTIC REGRESSION ANALYSIS}

Binary logistic regression analysis was done to predict the development of Met $\mathrm{S}$ by using serum NO, ET-1 and TSH as a predictor. The logistic regression model was statistically significant, $\chi^{2}(2)=106, p<0.001$. The model explained $79.5 \%$ of the variance in Met S. Nagelkerke's $\mathrm{R}^{2}$ of 0.795 indicating a moderately strong relationship between prediction and grouping. We found that $\mathrm{NO}(p<$ 0.001 , Odd ratio $=0.951,95 \% \mathrm{CI}=2.6-12.7), \mathrm{ET}-1$ $(p<0.001$, Odd ratio $=2.3,95 \% \mathrm{CI}=1.008-5.104)$ and TSH $(p<0.001$, Odd ratio $=5.8,95 \% \mathrm{CI}=$ 2.6-12.7) had significant predictability for Met $\mathrm{S}$. Odd's ratio value indicates that when serum NO is raised by one unit the odds ratio is 0.951 times as small and therefore individuals are 0.951 times less likely to develop Met S, likewise when serum ET-1 is raised by one unit the odds ratio is 2.3 times as large and therefore individuals are 2.3 times more likely to develop Met S and when serum TSH is raised by one unit the odds ratio is 5.8 times as large and therefore individuals are 5.8 times more likely to develop Met S.

\section{DISCUSSION}

Met $\mathrm{S}$ cases were found to have endothelial dysfunction as evidenced by decrease in mean levels of serum NO and increase in mean levels of serum Endothelin-1. The cases of Met S also had hidden $\mathrm{SCH}$ as compared to healthy controls. Mean serum NO levels were found to be lower in Met S cases having $\mathrm{SCH}$ as compared to Met $\mathrm{S}$ cases without SCH. Likewise mean serum Endothelin-1 levels were higher in Met S cases with $\mathrm{SCH}$ as compared to Met $\mathrm{S}$ cases without $\mathrm{SCH}$. Rise in TSH levels in Met S with SCH may be involved in the pathogenesis of endothelial dysfunction in Met S.

Subclinical hypothyroidism is a disorder characterized by elevated serum TSH levels despite normal $T_{3} \& T_{4}$ thyroid hormones without any clinical signs and symptoms of thyroid abnormality. The association between $\mathrm{SCH}$ and Met $\mathrm{S}$ has been one of the most sought after topics nowadays in the field of endocrinology research [9].

It has been seen that $\mathrm{SCH}$ is associated with obesity related co-morbidities such as Met $\mathrm{S}$, type 2 diabetes mellitus, cardiovascular disease, etc. It is unclear whether this association is due to endothelial dysfunction or change in lipid profiles [10].

Endothelium is not just an inert physical barrier, but a vital organ which helps in maintaining the vascular function by releasing vasodilatory mediators, such as NO, and vasoconstrictive mediators, such as ET-1. Endothelial dysfunction develops when there is reduced bioavailability of $\mathrm{NO}$ and increase in vasoconstrictive mediators such as ET-1. Endothelial dysfunction is considered as an early biomarker of Met S, type 2 diabetes mellitus, cardiovascular disease [11].

The predisposition of Met S patients with $\mathrm{SCH}$ towards endothelial dysfunction may be attributed due to the changes in lipid profile, low grade chronic inflammation, insulin resistance, oxidative stress and other unidentified factors. The raised $\mathrm{TSH}$ hormone in $\mathrm{SCH}$ may have extra thyroidal action as TSH receptors are found to be also present on endothelial cells and liver cells [12].

The study done by Mehran et al. showed that some cases of Met $\mathrm{S}$ have thyroid abnormalities and mean TSH levels were higher in cases of Met S with sub clinical hypothyroidism as compared to Met $\mathrm{S}$ cases without sub clinical hypothyroidism [13]. This finding is very similar to our findings with larger sample size and more statistically significant results, however their study is cross-sectional and no assessment of endothelial dysfunction has been done. Also, the cause of Met S in context with the presence of $\mathrm{SCH}$ is not being discussed. The present study is case control and assessment of various markers of endothelial dysfunction has been done in the study population.

Tian et al. explained the association of endothelial dysfunction and increased TSH level by putting forward the theories that TSH promotes endothelial dysfunction by attenuation of eNOS and prostacyclin expression [14]. Nevertheless, the intimate molecular mechanism of the interaction between TSH and vascular system is yet to be fully elucidated.

A study done by Turemen EE et al. also states that $\mathrm{SCH}$ is associated with endothelial dysfunction and TSH is positively correlated with endothelial dysfunction which explain that TSH plays some role in the pathogenesis of endothelial dysfunction. But they mentioned that its etiology is autoimmune in nature as they studied it on autoimmune thyroiditis patients [15].

Dardano A et al. studied the direct effect of $\mathrm{TSH}$ in vitro on endothelial dysfunction. They administered the recombinant human TSH directly on the endothelium and observed endothelial dysfunction. In this study, they considered inflammation and oxidative stress as the culprit for the development of endothelial dysfunction [16] 


\section{DYSLIPIDEMIA}

Dyslipidemia is also considered one of the culprits for developing endothelial dysfunction in Met $\mathrm{S}$ patients. It has been reported that NO synthesis pathways may be disturbed by hyperlipidemia by increased levels of asymmetric dimethylarginine (ADMA) in endothelial cells, which is considered as endogenous NO synthesis inhibitor [17]. High density lipoprotein (HDL) cholesterol has a beneficial role on the endothelium and helps in alleviating endothelial dysfunction by stimulating NO release and causing vasodilatations by pathways such as Akt-mediated eNOS phosphorylation and intracellular $\mathrm{Ca}^{2+}$ mobilization [18].

\section{INSULIN RESISTANCE}

Insulin resistance is also involved in the pathogenesis of endothelial dysfunction. In the normal physiological state, insulin stimulates the endothelial cells to produce NO and ET-1 through eNOS by PI3-K and MAPK pathway respectively. The critical balance between NO and ET-1 is responsible for maintaining normal endothelial function. In pathological state of insulin resistance, NO production by PI3-K pathway gets impaired but continuously stimulates ET-1 production due to stimulatory effect of hyperinsulinemia by MAPK pathway, which ultimately leads to endothelial dysfunction [11].

Hence, alteration of lipid profile, inflammatory status, insulin resistance in Met S patients with $\mathrm{SCH}$ may be due to various detrimental effect of raised TSH contributing to endothelial dysfunction. An early thyroxin replacement therapy may attenuate the endothelial dysfunction in such cases. However, all these factors interacted with each other, with none playing the decisive role alone in the pathogenesis of endothelial dysfunction in Met $\mathrm{S}$. The proposed mechanism in our study is shown in Figure 7.

In our study, TSH is positively correlated with various markers of endothelial dysfunction, and, therefore, could be promising to understand the mechanisms underlying the correlation between $\mathrm{SCH}$ and endothelial dysfunction. All these studied factors indicate that thyroid hormone replacement therapy may be beneficial to endothelial dysfunction. However, thyroxin replacement therapy would also increase the risk of osteopenia and atrial fibrillation, and there remain controversial opinions on substitution treatment, particularly for the elderly.

Strength of our study was 1) well standardized method to determine the study variables, characterized and diverse study populations, 2) data appropriately collected from study populations, 3 ) age and sex matched study populations.

\section{LIMITATIONS}

Our study was a hospital based cross sectional study so that we cannot predict cause and effect relationship. Our study had a small sample size.

\section{SUGGESTIONS}

We should go for large sample size and it should be a follow-up study with thyroid hormone replacement in Met S patients with SCH and analyse its effect on mediators of endothelial dysfunction.

\section{CONCLUSION}

Met $\mathrm{S}$ cases were found to have endothelial dysfunction and underlying $\mathrm{SCH}$. $\mathrm{SCH}$ in Met S may cause altered endothelium physiology which was found to be associated with a decrease in serum NO and an increase in serum ET-1 levels, leading to endothelial dysfunction and associated co-morbidities. The present study gives new insight in linking endothelial dysfunction and raised TSH levels in Met S. Therefore, Met S cases should be screened for $\mathrm{SCH}$ and treated appropriately to attenuate endothelial dysfunction and associated co-morbidities in Met $\mathrm{S}$.

Conflict of Interest: No conflict of interest to declare.

Acknowledgements. Special thanks to Dr Bhawesh Mishra, Dr Shilpa Bhardwaj and other technical staff of the Department of Biochemistry, Lady Hardinge Medical College, New Delhi, India.

Funding: Funding was provided by ICMR, New Delhi MD/MS Thesis grant.

Introducere. Disfuncția endotelială este considerată ca fiind unul din factorii importanți în patogeneza sindromului metabolic (Met S). Hipotiroidismul sublcinic (SCH) se asociază cu Met S. Obiectivul studiului a fost de a evalua asocierea 
nivelurilor crescute de TSH cu mediatori ai disfuncției endoteliale la pacienții cu Met S şi SCH comparativ cu martorii sănătoşi.

Material şi metodă. Au fost selecționați 100 de pacienți: 50 aveau Met $S$ şi 50 erau martori sănătoşi. În cadrul grupului cu Met $S$ erau pacienți care aveau SCH. Au fost analizate nivelurile serice ale insulinei, T3, T4, TSH prin chemiluminiscență. Nivelurile NO serice au fost analizate folosind metoda Griess modificată iar nivelurile endotelinei 1 (ET-1) au fost analizate cu ELISA.

Rezultate. Din cei 50 de pacienți cu Met S, 22 aveau SCH. Nivelurile medii serice ale TSH au fost semnificativ mai mari la pacienții cu Met $S$ comparativ cu martorii sănătoşi $(5.7 \pm 1.2 \mu \mathrm{IU} / \mathrm{mL}$ vs. $2.3 \pm 1.6 \mu \mathrm{IU} / \mathrm{mL}, P<0.0001)$. Nivelurile serice ale NO au fost semnificativ statistic mai mici la pacienții cu Met $S$ comparativ cu martorii sănătoşi $(15.4 \pm 10 \mu M$ vs. $21 \pm 10 \mu M, p=0.009)$. Nivelurile serice ale ET-1 au fost semnificativ statistic mai mari la pacienții cu Met $S$ comparativ cu martorii sănătoşi $(2.68 \pm 1.7 \mathrm{fmol} / \mathrm{ml} v s .2 .1 \pm 0.84 \mathrm{fmol} / \mathrm{mL}, p=$ 0.011). Nivelurile TSH au fost corelate pozitiv cu nivelurile serice ET-1 $(r=0.341$, $p=0.001)$ şi negativ cu nivelurile NO serice $(r=-0.331, p=0001)$. Analiza de regresie a demonstrat că nivelurile TSH, NO şi ET-1 prezic independent Met $S$.

Concluzii. Pacienții cu Met $S$ au SCH (prevalența in lotul studiat fiind de 44\%) precum şi disfuncție endotelială. Nivelurile crescute ale TSH-ului la pacienții cu SCH ar putea determina o disfuncție endotelială ceea ce poate duce la apariția Met $S$. Aşadar pacienții cu Met $S$ ar trebui căutați pentru $S C H$ şi tratați pentru această afecțiune pentru a preveni dezvoltatrea disfuncției endoteliale şi a comorbidităților asociate Met $S$.

Correspondence to: Dr Ashok Kumar Ahirwar, MBBS, MD, Senior Resident,

Department of Biochemistry, All India Institute of Medical Sciences (AIIMS), New Delhi

Address of correspondence: Room no. 3013, Department of Biochemistry, Third Floor,

Teaching Block, AIIMS, Ansari Nagar, New Delhi-110029.

Mobile no: +919654210832

E-mail: drashoklhmc@gmail.com

\section{REFERENCES}

1. AHIRWAR AK., JAIN A., GOSWAMI B., BHATNAGAR MK., BHATACHARJEE J. Imbalance between protective (adiponectin) and prothrombotic (Plasminogen Activator Inhibitor-1) adipokines in metabolic syndrome. Diab Met Syndr: Clin Res Rev. 2014; 8 (3):152-5.

2. ALBERTI G., ZIMMET P., SHAW J., GRUNDY SM. The IDF consensus worldwide definition of the metabolic syndrome. Brussels: International Diabetes Federation. 2006 Nov 8:1-23.

3. MOZUMDAR A., LIGUORI G. Persistent increase of prevalence of metabolic syndrome among US adults: NHANES III to NHANES 1999-2006. Diabetes Care. 2011 Jan 1; 34 (1):216-9.

4. PRASAD DS., KABIR Z., DASH AK., DAS BC. Prevalence and risk factors for metabolic syndrome in Asian Indians: A community study from urban Eastern India. Journal of cardiovascular disease research. 2012 Sep 30; 3 (3):204-11.

5. TZIOMALOS K., ATHYROS VG., KARAGIANNIS A., MIKHAILIDIS DP. Endothelial dysfunction in metabolic syndrome: prevalence, pathogenesis and management. Nutrition, Metabolism and Cardiovascular Diseases. 2010 Feb 28; 20 (2):140-6.

6. HADI HA., CARR CS., SUWAIDI JA. Endothelial dysfunction: cardiovascular risk factors, therapy, and outcome. Vascular health and risk management. 2005 Sep; 1 (3):183.

7. NIKNAM N., KHALILI N., KHOSRAVI E., NOURBAKHSH M. Endothelial dysfunction in patients with subclinical hypothyroidism and the effects of treatment with levothyroxine. Advanced biomedical research. 2016; 5.

8. MATHEW F., GLENDA J., JACK L. Quantification of nitric and nitrate in extracellular fluids. Metho Enzymol 1996; 268:237-46.

9. La Vignera S., Condorelli R., Vicari E., Calogero AE. Endothelial dysfunction and subclinical hypothyroidism: A brief review. J Endocrinol Invest. 2012; 35 (1): 96-103.

10. CABRAL MD., TEIXEIRA P., SOARES D., LEITE S., SALLES E., WAISMAN M. Effects of thyroxine replacement on endothelial function and carotid artery intima-media thickness in female patients with mild subclinical hypothyroidism. Clinics. 2011; 66 (8):1321-8.

11. AHIRWAR AK., JAIN A., SINGH A., GOSWAMI B., BHATNAGAR MK., BHATACHARJEE J. The study of markers of endothelial dysfunction in metabolic syndrome. Horm Mol Biol Clin Invest. 2015; 24 (3):131-6. 
12. BALZAN S., DEL CARRATORE R., NICOLINI G., BEFFY P., LUBRANO V., FORINI F et al. Proangiogenic effect of TSH in human microvascular endothelial cells through its membrane receptor. The Journal of Clinical Endocrinology \& Metabolism. 2012 Mar 14; 97 (5):1763-70.

13. MEHRAN L., AMOUZEGAR A., RAHIMABAD PK., TOHIDI M., TAHMASEBINEJAD Z., AZIZI F. Thyroid Function and Metabolic Syndrome: A Population-Based Thyroid Study. Hormone and Metabolic Research. 2017 Mar; 49 (03):192-200.

14. TIAN L., ZHANG L., LIU J., GUO T., GAO C., NI J. Effects of TSH on the function of human umbilical vein endothelial cells. Journal of molecular endocrinology. 2014 Apr 1; 52 (2):215-22.

15. TÜREMEN EE., CCETINARSLAN B., SAHIN T., CANTÜRK Z., TARKUN I. Endothelial dysfunction and low grade chronic inflammation in subclinical hypothyroidism due to autoimmune thyroiditis. Endocrine journal. 2011; 58 (5):349-54.

16. DARDANO A., GHIADONI L., PLANTINGA Y., CARACCIO N., BEMI A., DURANTI E et al. Recombinant human thyrotropin reduces endothelium-dependent vasodilation in patients monitored for differentiated thyroid carcinoma. The Journal of Clinical Endocrinology \& Metabolism. 2006 Oct; 91 (10):4175-8.

17. ITO A., TSAO PS., ADIMOOLAM S., KIMOTO M., OGAWA T., COOKE JP. Novel mechanism for endothelial dysfunction. Circulation. 1999 Jun 22; 99 (24):3092-5.

18. NOFER JR., VAN DER GIET M., TÖLLE M., WOLINSKA I., VON WNUCK LIPINSKI K., BABA HA. HDL induces NO-dependent vasorelaxation via the lysophospholipid receptor S1P 3. The Journal of clinical investigation. 2004 Feb $15 ; 113$ (4):569-81.

Received March 21, 2017 